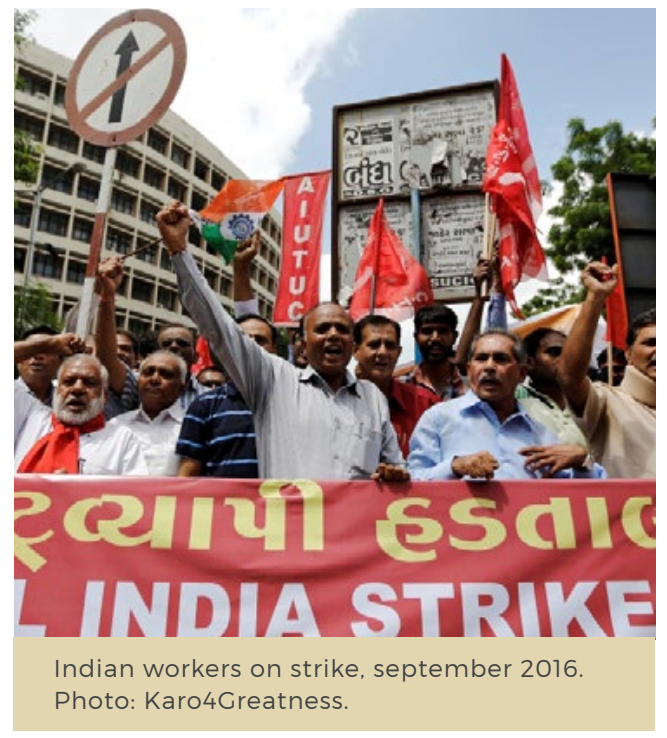

\section{Indian Labour Movements under Modi}

\section{Tom Barnes}

Indian labour politics today faces a historic paradox. On the one hand, in response to regressive changes to labour laws, India's trade unions have continued to organise what is, after China, the world's largest working-age population; on the other, massive labour protests have failed to make a dent in the political popularity of Prime Minister Narendra Modi and his right-wing Hindu nationalist Bharatiya Janata Party. To make sense of this apparent contradiction, this essay will outline the role of the Indian government in the formation of new labour law regulations since 2014, and the response of India's trade unions to this new challenge.
Indian labour politics today faces a historic paradox. On the one hand, India's vast labour movements have continued to organise what is, after China, the world's largest working-age population and to mobilise record numbers of workers in national street protests in response to regressive changes to labour laws. On the other hand, several massive labour protests have failed to make a dent in the political popularity of Prime Minister Narendra Modi and his right-wing Hindu nationalist Bharatiya Janata Party (BJP). Since 2014, the BJP has dominated government at the national level and at the local level in 13 states, including strategically-important and populous states like Uttar Pradesh and Maharashtra, as well as Rajasthan, Gujarat, and Haryana.

To explain this paradox, we need to look at the historical legacy of India's trade unions as well as the rise of the BJP, as part of a wider 'family of organisations' (Sangh Parivar), since the 1980s. Historically, the backbone of India's labour movement has been in the public sector and organised sector, which refers to all non-agricultural enterprises with ten or more employees. Despite the appearance of political strength, India's system of industrial relations never gave unions the right to collectively bargain with employers, and public sector wages and conditions were effectively fixed by the state. Unions were divided between competing federations-known as Central Trade Union Organisations (CTUOs)-each with different political party affiliations and most heavily reliant on political patronage.

Therefore, when India's economy stagnated and industrial conflict began to rise in the 1970s, the movement as a whole was poorly prepared to advance the interests of workers independently of state institutions or regional political classes. From that point onwards, the organised sector has declined as a proportion of total employment. The vast majority of new 
jobs created in the 1980s and 1990s were in small firms in the unorganised sector, which refers to enterprises with fewer than ten workers. Even when organised sector employment began to grow again in the 2000s, recruitment was increasingly dominated by the precariously employed, such as workers hired by labour contractors.

Despite the enormity of this challenge, the union movement grew significantly during the 'neoliberal' era of the 1990s and 2000s. Union membership doubled in India from 1989 to 2002 , which is the last year the national government verified trade union numbers based on complete records from all states (John 2007; Government of India 2008). Although unverified by the state, the most recent data released by the 12 officially-recognised CTUOs in 2012 and 2013 suggest that total membership may have increased by three or even four times since 2002 (Menon 2012). Much of this increase has come from informal workers.

It is on such a background that this essay will outline the role of BJP-led Governments at both national and regional levels in the formation of new labour law regulation since 2014, and the response of India's CTUOs to this new challenge.

\section{Modi's Labour Agenda}

Labour law reform is a major part of Narendra Modi's economic reform agenda, which is framed by the 'Make in India' initiative. This aims at making India the destination of choice for global manufacturing investment by continuing with previous governments' generous subsidies for large corporations and promises to cut governmental 'red tape'. Industrial conflict and union rights stand in the way of this dramatically ambitious agenda to challenge China's domination of global manufacturing.
Modi has expressed sympathy for reforms enacted by several BJP-led state governments in the areas of labour contractors and hire-and-fire flexibility. For example, the Governments of Rajasthan, Haryana, and Madhya Pradesh have made it easier for employers in organised sector firms to sack workers. This has been done by changing the rules established under the Industrial Disputes Act 1947 (IDA), making it possible for firms which employ 300 workers or more to make large-scale layoffs without state permission (previously the threshold was 100 workers). This change will be applied nationally if the Modi Government is able to pass its Labour Code, which aims to consolidate three central labour laws, including the IDA, into one simplified law. Although this code was introduced in April 2015 , its passage has been delayed by the slow pace of the Indian legislature and by opposition party control of the Rajya Sabha (upper house).

If passed, this Code would also extend the IDA's restrictions on strike action. Currently, public sector employees must give two weeks advance notice for any strike. The proposed change would extend this restriction to all workers and impose fines of 20,000 to 50,000 rupees (about 300 to 780 USD) and potential imprisonment for 'illegal' strike action (Gopalakrishnan and Sundar 2015). The Modi Government has also proposed changes to the Minimum Wage Act and the Apprenticeship Act, which would allow inter-state migrant workers to be hired as apprentices and sets their wages as a 'stipend' of 70 to 90 percent of the minimum wage, with no medical insurance.

While popular among industrialists, much of this mainstream labour law debate has focused on the small minority of regular workers employed in organised sector firms and does nothing to address the interests and rights of the majority of informal workers. Arguably, a more significant shift for informal workers involves proposed changes 
to social security. The Modi Government has already dramatically wound back the National Rural Employment Guarantee, which, since its inception in 2005, was supposed to provide 100 days of manual waged work (albeit at sub-minimum wages) for rural households. Now the government is proposing to collapse all existing social security provisions into the new unified Labour Code. If implemented, this reform would consolidate 15 separate laws into a single labour law (Gopalakrishnan 2017).

This would have a potentially dramatic impact on the rights of millions of poor informal workers. For example, labour activists have made major breakthroughs in some regions by organising workers to access entitlements through tripartite (employerunion-state) welfare boards. Many workers in informalised sectors, like construction or cigarette rolling, have benefited from death and accident insurance, maternity leave, education scholarships for their children, and funding for marriages. The new labour code threatens to undermine these hardwon rights by severely undermining these welfare boards.

\section{'Bharat Bandh'}

Since Modi's election in 2014, unionsled by the core of India's CTUOs-have periodically mobilised in large numbers to oppose the government's labour agenda. In September 2016, a massive nationwide strike caused major disruption to the economy. Some unions have claimed this was the largest general strike in history, with up to 150 million workers involved and costs to business of around 2.7 billion USD (Safi 2016). While these figures are impossible to verify, the strike was highly significant with virtually all public sector units, banks, and electricity power stations closed, in addition to insurance companies and, in many regions, trains, bus services, and schools
(Jagannathan 2016). Additionally, tens of thousands of coal miners joined the strike, along with university and college teachers (Live Mint 2016a; Reddy 2016). Many large private sector firms were also closed down or substantially affected.

This Bharat Bandh-literally 'India closed' in Hindi/Sanskrit-was the result of coordinated action by ten CTUOs who promoted a 12-point charter of demands on the Modi government (Live Mint 2016b). These demands include calls to expand subsidised food schemes, enforce existing labour laws (including minimum wages), implement universal social security, end the privatisation of public sector units, and ban foreign investment in railways and defence (Industriall Global Union 2016). The same CTUOs had organised another national strike in September 2015, which attracted a similar number of participants (Australia Asia Worker Links 2015). In February 2013, tens of millions had also joined a national strike (Australia Asia Worker Links 2013).

The scale of these successive protests demonstrates not only the sheer size of the Indian working class-the official labour force count is around 500 million, although the true figure is probably much larger-but also that CTUOs have been growing steadily in recent years. Still, in spite of these numbers and despite the BJP facing a new test in the Gujarat State elections at the time of writing, these protests have made little difference to Modi's sustained popularity as a politician and to the success of the BJP in state elections.

\section{Explaining the Paradox}

What explains the apparent contradiction between massive labour protests and a failure to change the direction of Indian politics? One reason is that India's polity and civil society is extremely diverse and 'labour politics' represent just one relatively minor 
part of it. Another is that labour politics tends to be squeezed outside mainstream debate by the country's political and media elite, who are largely hostile to unions.

A more fundamental reason relates to the BJP's historical success in appealing to a range of classes and castes, which fall between India's minority of industrialists and organised sector workers. As India's economy liberalised in the 1980s and 1990s, the BJP often succeeded in appealing to the interests of these intermediate classes' within a populist framework, while continuing to support and facilitate neoliberal economic policies (McCartney 2009). The BJP also appealed to the minority of salaried 'middle class' Indians in large cities-the well-educated, upwardlymobile sons and daughters of public sector employees and professionals who underpinned new markets for automobiles, electronic goods, and other trappings of consumer society.

This electoral appeal intersected with the rise of an immense anti-corruption movement in 2011 and 2012, which related to Indians' experience of everyday corruption. At the time, the movement severely undermined the Indian National Congressled national government. This confluence of factors meant that Modi, who cultivated an image as a 'clean', no-nonsense technocrat, was well positioned to take power in 2014, winning in a landslide.

\section{Beyond the Set-Piece}

Interestingly, many of the most significant social struggles since 2014 have occurred outside the set-piece events orchestrated by CTUOs. In the auto industry, a strike by 3,000 Honda workers in Tapukara in early 2016, 100 kilometres southwest of New Delhi, was heavily repressed by the state BJP government (Workers Solidarity Centre 2016). Over 1,000 workers were arrested,
136 workers fired, and dozens jailed. This came after the most serious conflict in the auto industry to-date, at Maruti Suzuki India Limited (MSIL) in the nearby town of Manesar. This conflict in 2011 and 2012 resulted in thousands of sackings, the tragic death of a human resources manager, and the imprisonment of dozens of workers.

Another important strike in 2016 took place in Bengaluru (Bangalore) where up to 400,000 workers emptied the city's garments factories and flooded the streets in response to government changes to state pensions (Bageshree and Bharadwaj 2016). Key features of this strike included its primarily 'wildcat' character-local CTUOs were taken by surprise, despite having organised their own, much smaller response to the changes-and that the strikers were overwhelmingly women. This massive protest succeeded in deferring the Modi government's plans (Aanchal Magazine 2016).

Given that women tend to work outside the male-dominated structures of most trade unions, another highly significant development occurred in the tea plantations of Munnar in Kerala in September 2015, when female plantation workers established a new women migrant-led union-Pembila Urumai ('Unity of Women' in Tamil)-to break with male-dominated unions (Banerji 2016).

While some of these workers may have participated in the CTUO-organised general strikes, the real challenges to the current polity have occurred in between these set-piece events, in a society in which the labour laws and social protections that have provoked such ferocious debate among industrialists, union federations, and political classes are so rarely applied. The Modi Government has signalled the intention to plough ahead with its controversial labour reform agenda, so further points of contention are likely to emerge. 
This text is taken from Gilded Age: A Year of Chinese Labour, Civil Society, and Rights, Made in China Yearbook 2017, edited by Ivan Franceschini and Nicholas Loubere, published 2018 by ANU Press, The Australian National University, Canberra, Australia.

doi.org/10.22459/MIC.04.2018.34 